\title{
Etse-Module "The Benefits of Acidic Bases in Life" Ethnoscience Based Demak Society in the Utilisation of Lime
}

\author{
Septia Nurkhalisa ${ }^{1}$, Fivi Fari Dhotul Ummayah ${ }^{1}$ \\ ${ }^{1}$ Universitas Negeri Semarang, Department of Integrated Science
}

\begin{abstract}
Teaching materials delivered by a teacher should be able to instil the character education of students through the culture and local wisdom that is around students who are integrated with the concepts that will be learned so that students can think scientifically about the phenomena they encounter every day. One way to incorporate local wisdom-based learning through the creation of ethnoscience-based modules. EtsE-Module it is an electronic module based on ethnoscience in Demak, a city in Central Java Indonesia which utilises lime as acne medicine on the acid-base material of Grade VII students in the first semester. Based on the results of the reconstruction of the science, the preparation of teaching materials can be loaded on the subject of science secondary school on the subject of acid and base. Students can discuss the process occurring in the phenomenon as well as inquire process on the topic according to the lesson plan that has been made by the teacher. The development of Ets-E-module is an electronic module based on local wisdom as the handling of junior high school students in studying IPA phenomena in the community.
\end{abstract}

Keywords: Teaching materials, Ethnoscience, acid-base topic, Etse-Module

\section{Introduction}

Education is a measure of the success of a nation because the quality of the nation is determined by the quality of education in the country. Trends in the International Mathematics and Science Study (TIMSS) is a study comparing mathematics and science achievement rates in various countries following it in 2015, the results in Indonesian science are ranked 45 out of 48 participants with below-average scores 397 [1]. In addition, a survey conducted by the Program for International Student Assessment (PISA), which is a study of science literacy students in various countries in the world in 2016 reported the results of science literacy students in Indonesia who ranked the bottom 10 of all countries in the world that follow PISA with a score of 403 [2]. Based on the scores obtained by Indonesian students only have the ability of science literacy to remember scientific knowledge such as facts, scientific names, simple formulas and scientific terms and evaluate an event, recognize the basic concept and have not been able to apply the concept in everyday life [3], [4].

The low level of student learning in Indonesia is caused by several factors. Some of these factors are the solid curriculum, the material on textbooks that are thought too difficult to understand, less effective learning media, inadequate laboratories, less precisely the use of learning media selected by teachers, less optimal and lack of student alignment itself, conventional nature, which makes students less involved in the learning process and the liveliness of the class is mostly dominated by the teacher [5]. Curriculum 2013 seeks to improve the quality of education in Indonesia in Regulation of Education and Cultural Minister Number 65 Year 2013 on Standards The process described that the learning process in the educational unit held interactively, inspirational, fun, challenging, motivate learners, to participate actively, Enough for initiative, creativity, and independence in accordance with the talents, interests, and physical and psychological development of learners. The change of learning into Curriculum 2013 according to [6] seven principles namely 1) learners who are told to be learners to find out; 2) the teacher as a learning resource to learn from various learning sources; 3) learning that emphasizes a single answer into multidimensional learning; 4) learning of verbalism toward learning that improves applicative skills; 5) improvement and balance between physical skills and mental skills; 6) learning takes place anywhere, including at school, at home, as well as in the community; 7) learning that apply Ki Hajar Dewantara's values ing ngarso sung tulodho (teacher should be model for students), ing madyo mangun karsa (in the midle teacher participate to helps students), and tut wuri handayani (from behind teacher should gives encouragement). Another factor besides the curriculum that becomes the basic problem in the improvement of education is the material in the textbook that students feel is too difficult because the material taught is not associated with the daily life of the students and it is still general.

Teaching materials delivered by a teacher should be able to instil the character education of students through the culture and local wisdom that is around students who are integrated with the concepts that will be learned so that students can think scientifically about the phenomena they encounter every day. One way to incorporate local wisdom-based learning through the creation of ethnoscience-based modules. Ethnoscience is genuine knowledge of society in the form of language, customs, culture, morals, and even technology made by societies in which there is a scientific knowledge that can be tested through literature review, scientific explanation, and scientific work [7]. Ethnoscience-based module is contextual by linking local wisdom around the student's residence into the lesson concept learned so that the learning that occurs will be more effective in improving student learning outcomes [8], improving students' cognitive abilities $90.63 \%$ [7], able to train students' science process

Volume 6 Issue 7, July 2017 


\section{International Journal of Science and Research (IJSR) \\ ISSN (Online): 2319-7064}

Index Copernicus Value (2015): 78.96 | Impact Factor (2015): 6.391

skills in $100 \%$ observation aspects, formulate problems, hypothesize, identify $71.43 \%$ variables and interpret data, draw conclusions, and communicate $100 \%$ data [9]. Learning process in the 21 st century is also can not be separated from technology. Based on the learning outcomes of ethnosciencebased learning, EtsE-Module it is an electronic module based on ethnoscience in Demak, a city in Central Java Indonesia which utilises lime as acne medicine on the acid-base material of Grade VII students in the first semester therefore students are expected to improve the process of scientific thinking Against the phenomena that exist around the students.

Ethnoscience-based module is contextual by linking local wisdom around the student's residence into the lesson concept learned so that the learning that occurs will be more effective in improving student learning outcomes [7], improving students' cognitive abilities $90.63 \%$ (Sudarmin et al, 2016), able to train students' science process skills in $100 \%$ observation aspects, formulate problems, hypothesize, identify $71.43 \%$ variables and interpret data, draw conclusions, and communicate $100 \%$ data [9]. Learning process in the 21 st century is also can not be separated from technology. Based on the learning outcomes of ethnosciencebased learning, EtsE-Module it is an electronic module based on ethnoscience in Demak, a city in Central Java Indonesia which utilises lime as acne medicine on the acid-base material of Grade VII students in the first semester therefore students are expected to improve the process of scientific thinking Against the phenomena that exist around the students.

\section{Discussion}

Indigenous Science in Science Learning can help the students in bridging the initial knowledge of the students therefore, we can bring them to learn the concepts according to the material in the learning curriculum. The genuine knowledge of society is one of the studies in ethnosciences that can be applied to learning resources in the classroom [7]. Ethno-based learning makes it easier for students to recognise facts, phenomena and events that exist in society and integrate with the scientific knowledge they learn hence students will be more interested in learning the concept in science [9]. The diversity of knowledge society in Indonesia can be a material for discussion of students in the classroom. Choosing the discussion materials during the learning process is a skill that teacher must have, especially the science teacher therefore as to be able to design the learning process in accordance with the objectives of Integrated Science learning materials are submitted and discussed in the classroom should be able to make students think critically. Teacher competence in preparing the learning materials will increase if the teacher has known the original knowledge that exists in the community therefore that the teacher can give an example to the students to related original knowledge in the community. This is evidenced by the research of [10] that prospective science teachers are able to prepare the teaching materials well after being given the task of analysing the original knowledge of the community in their residence area.
Learning based on ethnosciences is contextual learning, teachers have to know the environment around the students to associate social knowledge in the community into the learning process. Not all knowledge in society can be regarded as ethnosciences. The original knowledge of society must go through the first reconstruction phase into scientific knowledge. The reconstruction in question is the process of translating genuine scientific societies into scientific concepts, usually the original sciences of society derived through a process of direct observation in the culture therefore because the results of the reconstruction of original science are the concepts of science [11].

Based on the results of observations that have been done, the original science reconstruction of society in Demak in the utilisation of lime as acne medicine with the results in Table 1 .

Table 1: The result of the reconstruction of the original science of the Demak community on the utilisation of lime as acne medicine

\begin{tabular}{|c|c|c|}
\hline Topic & Indigenous Science & Scientific Science \\
\hline $\begin{array}{c}\text { How is the } \\
\text { effectiveness } \\
\text { of lime as acne } \\
\text { remover }\end{array}$ & $\begin{array}{l}\text { The average respondent } \\
\text { answered that lemon is } \\
\text { effective in removing } \\
\text { acne if its use is } \\
\text { frequent }\end{array}$ & $\begin{array}{c}\text { The use of lime as an } \\
\text { acne remedy according } \\
\text { to research [12] has an } \\
\text { increasingly longer } \\
\text { contact time and more } \\
\text { and more will make lime } \\
\text { more effective in } \\
\text { eliminating acne. }\end{array}$ \\
\hline $\begin{array}{l}\text { The effect is } \\
\text { felt by } \\
\text { respondents } \\
\text { when using } \\
\text { lime as acne } \\
\text { remover }\end{array}$ & $\begin{array}{c}\text { Respondents admitted } \\
\text { that after using lemon } \\
\text { felt sore (cache) on } \\
\text { acne. }\end{array}$ & $\begin{array}{c}\text { Painful at acne when } \\
\text { utilising lime as acne } \\
\text { remover is felt by some } \\
\text { sensitive skin types [13] }\end{array}$ \\
\hline \begin{tabular}{|c|} 
Why lime is \\
able to get rid \\
of acne
\end{tabular} & $\begin{array}{l}\text { Respondents said that } \\
\text { lemon is effective to } \\
\text { remove acne because } \\
\text { lemon contains acid } \\
\text { and there is vitamin C } \\
\text { in lime }\end{array}$ & $\begin{array}{l}\text { [14] shows that lime is } \\
\text { able to inhibit the growth } \\
\text { of Staphylococcus } \\
\text { aureus bacteria which is } \\
\text { one cause of acne. }\end{array}$ \\
\hline \begin{tabular}{|c|} 
The part of \\
lime that used \\
to remove acne \\
\end{tabular} & $\begin{array}{c}\begin{array}{c}\text { The average respondent } \\
\text { using juice or citrus } \\
\text { fruits }\end{array} \\
\end{array}$ & $\begin{array}{l}\text { The content of essential } \\
\text { oils and antibacterials } \\
\text { contained in lime juice }\end{array}$ \\
\hline \begin{tabular}{|} 
How many \\
times \\
respondents \\
use lime as an \\
acne remover
\end{tabular} & $\begin{array}{l}\text { To get rid of acne then } \\
\text { people apply lemon } \\
\text { every day until the acne } \\
\text { disappears }\end{array}$ & $\begin{array}{c}\text { Frequency of use of lime } \\
\text { as an acne medication } \\
\text { done for two to three } \\
\text { times a day including } \\
\text { contact time for five } \\
\text { minutes [12] }\end{array}$ \\
\hline
\end{tabular}

Based on the results of the reconstruction of the science, the preparation of teaching materials can be loaded on the subject of science secondary school on the subject of acid and base. Students can discuss the process occurring in the phenomenon as well as inquire process on the topic according to the lesson plan that has been made by the teacher.

\subsection{Acid-base Topic}

The concept of IPA on Demak community habits that utilise lime in overcoming acne can be associated with acidic and 


\section{International Journal of Science and Research (IJSR) \\ ISSN (Online): 2319-7064}

Index Copernicus Value (2015): 78.96 | Impact Factor (2015): 6.391

alkaline materials. The concept of acid and base is taught to the students of Secondary School VII grade of semester I. The material of acid and base is taught to students in the subchapter of acid, base, and salt solution. Acidic traits can convert blue litmus paper to red, the use of acids commonly found in digestive processes, present in foods and beverages or as home cleaning agents. Bases have characteristics that are slippery and somewhat bitter, turning red litmus paper into blue and are usually used in bath soap, laundry soap, shampoo, toothpaste, ulcer medication and also fertiliser. In addition, the application of acid in Demak society that uses acid contained in lime that is used to remove acne. The ability of lime in eliminating acne is caused because the bacteria that cause acne can not live in an acidic atmosphere [14]. In addition to the classification of acids and bases, the application of genuine knowledge of the community in applying lime as a remover acne in the community Demak also included in the classification of living things because the cause of acne is Staphylococcus aureus into the kingdom of bacteria.

\subsection{Module}

The learning process can not be separated from the use of teaching materials used. One of the teaching materials that can help the learning process is a module. Modules are teaching materials that are arranged systematically in accordance with the curriculum used in accordance with the circumstances and potentials around the students so that students are able to study it independently in a certain time unit so that students are able to master the competence taught [15]. Students use the module independently so that the module is presented with good, interesting, illustrated and pictorial language in order to motivate students to understand science learning [16]. The development of the module based on ethnosciences has been done by many researchers before and able to improve the learning outcomes and the character of the students according to Table 2. Based on various research using e-module in the learning process, e-module gives good influence to the students' Can be seen in Table 2.

Table 2: The result of students learning outcome using emodule and ethnosciene

\begin{tabular}{|c|c|}
\hline Source & Result \\
\hline $\begin{array}{c}\text { [17] (Kustanti et } \\
a l, 2016)\end{array}$ & $\begin{array}{l}\text { The development of Integrated Science e- } \\
\text { module based on service learning on the theme } \\
\text { of "Air Pollution" can increase the critical } \\
\text { thinking ability of VII grade students by } \\
72.40 \% \text { at the first meeting and } 83.98 \% \text { at the } \\
\text { second meeting. }\end{array}$ \\
\hline $\begin{array}{c}\text { [18] (Perdana } e t \\
a l, 2017)\end{array}$ & $\begin{array}{l}\text { E-module learning media on science teaching } \\
\text { Motion Dynamics material integrated with } \\
\text { science process able to increase critical thinking } \\
\text { ability at activity focus on questions with } \\
\text { criteria } 95.41 \% \text {, observation and determination } \\
\text { result } 89.17 \% \text { observation, questioning and } \\
\text { answer classification question } 88.75 \% \text {, } \\
\text { evaluating and } 82.5 \% \text { try to determine } 82.5 \% \\
\text { action as well as e-module able to increase } \\
\text { student's motivation in learning. }\end{array}$ \\
\hline $\begin{array}{l}\text { [19] (Benjamin, } \\
\text { 2013) }\end{array}$ & $\begin{array}{l}\text { E-module can improve students learning } \\
\text { outcomes in India. }\end{array}$ \\
\hline [20] (Limatahu et & esearch on video-based electronic \\
\hline
\end{tabular}

\begin{tabular}{|c|c|}
\hline al, 2017) & $\begin{array}{c}\text { was conducted on students in Tidore Indonesia } \\
\text { who showed that there was an influence on } \\
\text { students after that module. Student process } \\
\text { skills become higher with 85\% value. }\end{array}$ \\
\hline $\begin{array}{c}\text { [21] (Diana et al, } \\
\text { 2015) }\end{array}$ & $\begin{array}{c}\text { E-module based problem based learning can } \\
\text { improve students' critical thinking skills and } \\
\text { reduce student misconceptions on ecological } \\
\text { topic. }\end{array}$ \\
\hline $\begin{array}{c}\text { [22] (Mahendrani, } \\
\text { 2015) }\end{array}$ & $\begin{array}{c}\text { The learning based on ethnoscience using } \\
\text { booklets can improve students' learning } \\
\text { outcomes in the cognitive domain with 86.44\% } \\
\text { classical completeness and able to invite } \\
\text { students to active in learning process. }\end{array}$ \\
\hline [23] (Rosyidah et \\
al, 2013) & $\begin{array}{c}\text { The development of IPA module based on } \\
\text { ethnoscience on Additive Substance materials } \\
\text { can improve student learning outcomes in SMP } \\
\text { Negeri 1 Pegandon Indonesia because 93.75\% } \\
\text { of students have reached minimum standarts . }\end{array}$ \\
\hline [24] (Rahayu, & $\begin{array}{c}\text { The development of Integrated Science module } \\
\text { based on ethnoscience on the theme of Energy } \\
\text { in Life is able to improve post test result with } \\
\text { gain value of 0.58 with medium criteria and to } \\
\text { develop student character. }\end{array}$ \\
\hline
\end{tabular}

The use of ethnoscience-based modules that improve student learning outcomes and character must be balanced with structured materials in modular form. Submission of material to students can not be separated from the development of existing technology. The learning process should be done with the development of e-module based ethnoscience, therefore, the learning process will be able to integrate the original knowledge of the people of Demak in eliminating acne using lemon as the study material in the science material of substrate classification of Acid, Basa and Salt in the process of technology-based learning.

\section{Conclussion}

The learning process is not only done in the classroom but the students can also learn from the environment and society. The development of Ets-E-module is an electronic module based on local wisdom as the handling of junior high school students in studying Integrated Science phenomena in the community.

\section{References}

[1] Provasnik, S., Malley, L., Stephens, M., Landeros, K. Perkins, R., and Tang, J.H. 2016. Highlights From TIMSS and TIMSS Advanced 2015: Mathematics and Science Achievement of U.S. Students in Grades 4 and 8 and in Advanced Courses at the End of High School in an International Context (NCES 2017-002).

[2] Washington, DC: U.S. Department of Education, National Center for Education Statistics. Retrieved (31 Maret 2016) from http://nces.ed.gov/pubsearch

[3] Wulandari, N dan Sholihin, H. 2016. Analisis Kemampuan Literasi Sains pada Aspek Pengetahuan dan Kompetensi Sains Siswa SMP pada Materi Kalor. EDUSAINS. 8(1): 67-73.

[4] Pratiwi, Y. I., Budiharti, R., Ekawati, E., Y. 2014. Pengembangan Media Pembelajaran IPA Terpadu Interaktif dalam Bentuk Moodle untuk Siswa SMP pada 


\section{International Journal of Science and Research (IJSR) \\ ISSN (Online): 2319-7064}

Index Copernicus Value (2015): 78.96 | Impact Factor (2015): 6.391

Tema Matahari sebagai Sumber Energi Alternatif. Jurnal Pendidikan Fisika.2(1): 26-30.

[5] Supardi U.S., Leonard, Suhendri, H., Rismurdiyati. 2012. Pengaruh Media Pembelajaran dan Minat Belajar Terhadap Hasil Belajar Fisika. Jurnal Formatif. 2(1): 71-81.

[6] Sudarno, Sunarno, W., \& Sarwanto. (2015). KONTEKSTUAL DENGAN TEMA PEMBUATAN TAHU KELAS VII. JURNAL INKUIRI, 4(3), 104-111.

[7] Sudarmin, Febu, R., Nuswowati, M., \& Suwarni, W. (2016). Development of Ethnoscience Approach in The Module Theme Substance Additives to Improve the Cognitive Learning Outcome and Student , s entrepreneurship Development of Ethnoscience Approach in The Module Theme Substance Additives to Improve the Cognitive L. In The 3rd International Conference on Mathematics, Science and Education (pp. 1-14). https://doi.org/10.1088/17426596/755/1/011001

[8] Nailiyah, M. R., Subiki, \& Wahyuni, S. (2016). Pengembangan modul ipa tematik berbasis etnosains kabupaten jember pada tema budidaya tanaman tembakau di smp. Jurnal Pembelajaran Fisika, 5(3), 261-269.

[9] Indrawati, M., \& Qosyim, A. (2017). KEEFEKTIFAN LEMBAR KERJA SISWA ( LKS ) BERBASIS ETNOSAINS PADA MATERI. E-Journal Unesa, (2011), 152-158.

[10] Parmin, Sajidan, Ashadi, Sutikno, \& Maretta, Y. (2016). Preparing Prospective Teachers in Integrating Science and Local Wisdom through Practicing Open Inquiry Preparing Prospective Teachers in Integrating Science and Local Wisdom through Practicing Open Inquiry. Journal of Turkish Science Education, 13(2), 3-14. https://doi.org/10.12973/tused.10163a

[11] Khusniati, M. (2014). MODEL PEMBELAJARAN SAINS BERBASIS KEARIFAN. Indonesian Journal of Conservation, 3(1), 67-74.

[12] Fuadah, N. N. 2017. Mengatasi Wajah Berjerawat, Perih Setelah Perawatan di Klinik Kecantikan. http://www.alodokter.com/komunitas/topic/kenapa-kulitwajah-terasa-perih (retrieved 14 April 2017).

[13] Razak, A., Djamal, A., Revilla, G. 2013. Uji Daya Hambat Air Perasan Buah Jeruk Nipis (Citrus aurantifolia s.) Terhadap Pertumbuhan Bakteri Staphylococcus Aureus Secara In Vitro. Jurnal Kesehatan Andalas. 2(1): 5-8.

[14] Fuadah, N. N. 2017. Mengatasi Wajah Berjerawat, Perih Setelah Perawatan di Klinik Kecantikan. http://www.alodokter.com/komunitas/topic/kenapa-kulitwajah-terasa-perih (retrieved 14 April 2017).

[15]Lauma, S. W., Damajanty H. C. P., Bernart S. P. H. 2015. Uji Efektifitas Perasan Air Jeruk Nipis (Citrus aurantifolia $S$ ) Terhadap Pertumbuhan Bakteri Staphylococcus aureus Secara Invitro. PHARMACON Jurnal Ilmiah Farmasi. 4(4): 9-15.

[16] Nisa', A., Sudarmin, \& Samini. (2015). EFEKTIVITAS PENGGUNAAN MODUL TERINTEGRASI ETNOSAINS DALAM PEMBELAJARAN BERBASIS MASALAH UNTUK MENINGKATKAN LITERASI SAINS SISWA. Unnes Science Education Journal, 4(3), 1049-1056.
[17]Lestari, Sarwanto, \& Masykuri, M. (2015). PENGEMBANGAN MODUL IPA TERPADU DENGAN PENDEKATAN SAINTIFIK TEMA SAMPAH UNTUK KELAS VII SMP / MTs. JURNAL INKUIRI, 4(2), 116-124.

[18] Kustanti, F., Nurohman, S., \& Widowati, A. (2016). PENGEMBANGAN E-MODULE IPA BERBASIS SERVICE LEARNING DENGAN TEMA “ PENCEMARAN UDARA " UNTUK TO IMPROVE THE CRITICAL THINKING SKILL FOR GRADE VII STUDENTS OF JUNIOR. Jurnal Pendidikan Matematika Dan Sains, 1-6.

[19]Perdana, F. A., sarwanto, sukarmin, \& Sujadi, I. (2017). Development of e-module combining science process skills and dynamics motion material to increasing critical thinking skills and improve student learning motivation senior high school. International Journal of Science and Applied $\quad$ Science, $\quad 1(1), \quad 45-54$. https://doi.org/10.20961/ijsascs.v1i1.5112

[20] Benjamin, A. E. W. (2013). Effectiveness of E- Learning Modules in Science at the Higher Secondary School Level in India. Indian Journal of Applied Research, 3(4), 122-124.

[21] Limatahu, N. A., Rahman, N. A., Abu, S. H. N., \& Cipta, I. (2017). Pengaruh Video Praktikum Dengan Modul Elektronik Terhadap Keterampilan Proses Pada Materi Stoikiometri Siswa Kelas X SMAN 2 Tidore Kepulauan. Jurnal Pendidikan Kimia (JPKim, 9(1), 225-228.

[22] Diana, N., Karyanto, P., Suciati, \& Indriyati. (2015). Penerapan E-Module Berbasis Problem-Based Learning untuk Meningkatkan Kemampuan Berpikir Kritis dan Mengurangi Miskonsepsi pada Materi Ekologi Siswa Kelas X MIPA 1 SMA Negeri 5 Surakarta Tahun Pelajaran 2014 / 2015. In Seminar Nasional XII Pendidikan Biologi FKIP UNS 2015 (pp. 242-247).

[23] Mahendrani, K., \& Sudarmin. (2015). PENGEMBANGAN BOOKLET ETNOSAINS FOTOGRAFI TEMA EKOSISTEM UNTUK MENINGKATKAN HASIL BELAJAR PADA SISWA SMP. Unnes Science Education Journal, 4(2), 865-872.

[24] Rosyidah, A. N., Sudarmin, \& Siadi, K. (2013). Pengembangan Modul IPA Berbasis Etnosains Zat Aditf dalam Bahan Makanan untuk Kelas VIII SMP Negeri 1 Pegandon Kendal. Unnes Science Education Journal, 2(1), 133-139.

[25] Rahayu, W. E., \& Sudarmin. (2015). PENGEMBANGAN MODUL IPA TERPADU BERBASIS ETNOSAINS TEMA ENERGI DALAM KEHIDUPAN UNTUK MENANAMKAN JIWA KONSERVASI SISWA. Unnes Science Education Journal, 4(2), 919-926.

\section{Author Profile}

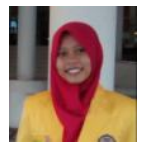

Septia Nurkhalisa Study Universitas Negeri Semarang, Department of Integrated Science During 2015-now. Focuse research on Integrated Education Development. 
